\title{
Monitoring pearl farming lagoon temperature with global high resolution satellite-derived products: An evaluation using Raroia Atoll, French Polynesia
}

\author{
Van Wynsberge Simon ${ }^{1,}{ }^{*}$, Le Gendre Romain ${ }^{1}$, Sangare Nathanaël 2, 3 , Aucan Jérôme ${ }^{2}$, \\ Menkes Christophe ${ }^{2}$, Liao Vetea ${ }^{4}$, Andréfouët Serge ${ }^{2}$
}

\begin{abstract}
1 Ifremer, IRD, Univ Nouvelle-Calédonie, Univ LaRéunion, CNRS, ENTROPIE, F-98800 Nouméa, New Caledonia

2 Institut de Recherche pour le Développement, UMR 9220 ENTROPIE (Institut de Recherche Pour le Développement, Université de la Réunion, IFREMER, Université de la Nouvelle-Calédonie, Centre National de la Recherche Scientifique), BP A5, 98848 Nouméa cedex, New Caledonia 3 Ifremer, IRD, Institut Louis-Malardé, Univ Polynésie française, EIO, F-98719 Taravao Tahiti, French

Polynesia

4 Direction des Ressources Marines, Papeete, French Polynesia

*Corresponding author : Simon Van Wynsberge, email address : simon.van.wynsberge@ifremer.fr
\end{abstract}

\begin{abstract}
:
Temperature is important for pearl oyster reproduction, pelagic larval duration, and growth in the context of pearl farming, but has seldom been monitored over long periods in remote atolls. To test if satellite-derived Sea Surface Temperature (SST) could provide a solution, two daily global SST products were compared with 18 high-precision loggers deployed during 10-months in the wide Raroia atoll (Tuamotu Archipelago, French Polynesia). The Multi-scale-Ultra-high-Resolution (MUR) SST was better correlated with lagoon temperature $(r>0.97)$ than the Global-Foundation-Sea-Surface-Temperature-Analysis (G1SST) SST $(r<0.94)$. Differences between observations and MUR SST ranged between $-0.75^{\circ} \mathrm{C}$ and $+1.12^{\circ} \mathrm{C}$ and were influenced by seasons and locations, depth, and hours of measurements. Within this uncertainty range, simulations using a Dynamic Energy Budget model predicted similar life traits of oysters. Therefore, MUR SST appears suitable to monitor lagoon temperature in wide atolls, model oyster population dynamics and assist pearl oyster research and management.
\end{abstract}

\section{Highlights}

- We found a maximal difference between MUR and lagoon temperature of $1.12{ }^{\circ} \mathrm{C}$. Highest differences between SST and lagoon temperature were found during the warm season. The differences between SST and lagoon temperature had negligible influence on pearl oyster life traits.

Keywords : Sea surface temperature, Satellite SST, Pinctada margaritifera, Dynamic Energy Budget, MUR SST, G1SST 


\section{Introduction}

The pearl oyster (Pinctada margaritifera) is the most valuable farmed species in French Polynesia. This species allows the production of black pearls, yielding an export value of $\sim 70$ million euros in 2017 (IEOM, 2018). The pearl farming activity takes place in 29 French Polynesia lagoons (DRM, 2020). In 2019, 26 atolls and islands practiced spat collection and rearing of grafted oysters, while 3 more focussed only on spat collecting. Most of the activity takes place in the Tuamotu Archipelago, where 12 atolls are very active, and in the Gambier Islands. This activity provides substantial income for inhabitants in atolls where other opportunities are limited. However, environmental problems are frequent and have increasingly impaired farming success in several lagoons, with oyster diseases, water quality issues and phytoplanktonic blooms resulting in massive mortalities (Andréfouët et al. 2015; Rodier et al. 2019).

The sustainability of pearl oyster farming in atolls is uncertain in the context of global warming. Temperature in atoll lagoons of the Tuamotu Archipelago can frequently reach $30-32{ }^{\circ} \mathrm{C}$ (Van Wynsberge et al. 2017), which is well above the thermal optimum of $P$. margaritifera for somatic growth and reproduction (Le Moullac et al. 2016). Increasing temperature in atoll lagoons due to climate change may affect the success of pearl oyster culture in various ways (Bell et al. 2011; 2013), including decrease of spat collection, oyster growth and pearl quality (Le Moullac et al. 2016; Latchere et al. 2018). In fact, pearl oyster's life traits depend on temperature levels and variations over both short-time ( days/week; e.g., spawning induction and larvae growth), and long-time-scales ( months/year; adult growth and gonad maturation) (Sangare et al. 2020). Several research programs have investigated the processes by which warming of farmed lagoons may affect the pearl farming industry. In particular, laboratory experiments, in situ measurements, and modelling, including with Dynamic Energy Budget (DEB) models, are used to understand how temperature affects $P$. margaritifera's life traits, and to estimate the risk of approaching its 
physiological limits with the projected future high temperature (Le Moullac et al. 2016; Sangare et al. 2020).

A major challenge to understand the future risks related to lagoon warming is to access long-term temperature time-series that are representative of the conditions experienced by both the wild and cultivated pearl oysters. Long-term time series of temperature are needed to relate population dynamics to temperature. Reproduction maturation and spawning, growth and mortality are all dependent on temperature variations at different time-scale. In particular, addressing climatechange related effects on oyster physiology and dynamics, as well as adaptation processes, need tracking changes in pearl oysters thermal environment over decades. Due to the remoteness of many pearl farming atolls, the maintenance of temperature loggers over long periods would be very costly in equipment and maintenance, even if focussing on only the 12 most important sites. In the past, most temperature series have been discontinuous, using different types of sensors with various precisions, sampling rates and autonomy time, resulting in limited temporal coverage and disparate dataset. In the future, deploying high-precision sensors, including sensors able to communicate in real-time, is an option (Liao et al. this issue). But this will not inform on the past conditions (i.e., during the past decade), preventing the analysis of long data series. Other solutions that could be cost-effective and retroactive must be evaluated, including using remote sensing products.

High resolution satellite-derived Sea Surface Temperature (SST) products offer interesting perspectives to monitor atoll lagoons. Retrievals from satellite infra-red sensors can sample SST even for the most remote areas where long-term in situ data are unavailable. Several infra-red sensors provide SST data at $1 \mathrm{~km}$ spatial resolution such as the Moderate Resolution Imaging Spectroradiometer (MODIS) and the Visible Infra-Red Imaging Radiometer Suite (VIIRS), or even at higher spatial resolution (e.g., sensors aboard Landsat-8 satellite, $30 \mathrm{~m}$ resolution) albeit at lower temporal frequency. For spaceborne missions providing a daily revisit time, their spatial resolution is still an order of magnitude finer than the size of the largest pearl farming atolls, such as Arutua 
or Raroia, and therefore can provide SST measurements inside their lagoons. However, these sensors have intrinsic limitations. First, satellite-derived SST represents the temperature of a thin $(\simeq 0.01 \mathrm{~mm})$ boundary layer at the air-sea interface (i.e., the "skin" layer) which differs from the bulk SST that would characterize the actual environment of the wild or farmed oysters. The farmed oysters typically live from the sub-surface down to 10 meters for spat collectors and reared stocks. The wild stocks is present from the subsurface down to 40 meters, with variations depending on each atoll (Zanini and Salvat, 2000; Andréfouët al. 2016). Furthermore, cloud cover often affects SST estimates from infra-red sensors, generating data gaps that limit continuous temporal coverage. Finally, at $1 \mathrm{~km}$ resolution, pixels mixing land and water necessarily occur along the atolls rims which are typically $\sim 1 \mathrm{~km}$ large or less. Taking that uncertainty into account, there is a $\sim 3 \mathrm{~km}$-wide domain of uncertain data along the rim.

To limit the uncertainty on SST induced by the skin layer and cloud cover, global SST products combining satellite data and in-situ observations have been developed (e.g., the Operational Sea Surface Temperature and Sea Ice Analysis OSTIA; see Donlon et al. 2012). These products provide a daily SST more representative of the bulk SST and free of data gaps due to clouds. Until recently, typical grid resolution of daily global SST analysis products ranged from $0.05^{\circ} \times 0.05^{\circ}$ to $0.25^{\circ} \times$ $0.25^{\circ}$ ( $\sim 5$ to $25 \mathrm{~km}$, e.g., Donlon et al. 2012). Due to the spatial and temporal averaging applied for interpolation, the actual resolution of the physical features can be substantially coarser than the grid resolutions (Reynolds and Chelton 2010; Reynolds et al. 2013). Therefore, these products were deemed suitable for open ocean only and remained invalidated for small water bodies like atoll lagoons, even the largest ones. For atolls in the Tuamotu Archipelago, temperature inside the lagoon significantly differs from ocean temperature, which precludes using ocean SST as proxy of lagoon temperature, without correction (Van Wynsberge et al. 2017). Recently, however, new global SST products have been developed by the Group for High Resolution Sea Surface Temperature (GHRSST), that use the $\sim 1 \mathrm{~km}$ resolution MODIS data and can capture small scale 
features better than previous products. This includes the Multi-scale Ultra high Resolution (MUR) analysis of global sea surface temperature (Chin et al. 2017) and the G1SST Global Foundation Sea Surface Temperature Analysis (Chao et al. 2009). These products could bring new perspectives for monitoring temperature of pearl farming atoll lagoons.

In this study, we compare the $1 \mathrm{~km}$-resolution SST provided by MUR and G1SST against a large array of temperature sensors deployed during 10 months across the $359 \mathrm{~km}^{2}$ of the Raroia Atoll lagoon, in the Tuamotu Archipelago. The goal is to precisely evaluate if data extracted from global SST products can accurately represent the bulk temperature environment of oysters in different part of the lagoons.

First, temperature patterns in the lagoon are described based on the array of in situ observations. Differences between lagoon temperature and ocean temperature recorded in situ on reef slopes are also documented. Second, we compare G1SST and MUR SST with in situ observations to assess their ability to capture lagoon and intra-lagoon features. This exercise is performed using temperature data integrated over various time scales (from 1 to 15 days). Indeed, daily temperature data may not be necessarily relevant for physiological processes occurring at longer time-scale (several days to weeks). Finally, we assess what would be the influence of using SST instead of in situ temperature measurements when modelling oyster populations throughout their life cycle. For that purpose, DEB simulations of $P$. margaritifera's growth, pelagic larval duration, and adult reproductive effort, were computed using SST on the first hand, and in situ temperature data on the other hand. This study eventually clarifies the potential and limits of using global SST products to support pearl farming research and management.

\section{Methods}

Study site description 
Raroia atoll is located in the Tuamotu Archipelago (142 $\left.{ }^{\circ} \mathrm{W} ; 16^{\circ} \mathrm{S}\right), 750 \mathrm{~km}$ east of Tahiti, the main island of French Polynesia (Fig. 1A). It is a famous atoll due to the landing of the Kon-Tiki raft in 1947 and with some of the earlier scientific work achieved in South Pacific atolls (Newell 1953). Seasonal variations are low in this area, with offshore sea surface temperature usually ranging between $26{ }^{\circ} \mathrm{C}$ in August and $30{ }^{\circ} \mathrm{C}$ in March. Northeasterlies associated with highpressure systems are predominant almost year-round (Dutheil et al. this issue).

The lagoon of Raroia is a $359 \mathrm{~km}^{2}$ water body with a maximum depth of $68 \mathrm{~m}$ (Andréfouët et al. this issue). It is connected to the ocean through a $500 \mathrm{~m}$-wide and deep reef pass $(\sim 6 \mathrm{~m}$ in its shallowest section and $\sim 15 \mathrm{~m}$ in its deepest section) in the north-western part of the rim. Many shallow channels, called hoa, are also present in the eastern part of the rim allowing water flow into the lagoon when there are incident waves. These channels are much less numerous across the western part of the rim. Finally, a $5 \mathrm{~km}$-long reef flat in its southern part also allows oceanic water entrance especially during southern swells (Fig. 1B). Oceanic and lagoon tides and surges modulate water entrance in all these opening. Oceanic and lagoon tidal ranges at Raroia reach respectively 1 $\mathrm{m}$ and $0.55 \mathrm{~m}$ during spring tide and $0.45 \mathrm{~m}$ and $0.25 \mathrm{~m}$ during neap tide (Aucan et al. this issue). Due to its pass and its numerous hoa, Raroia can be qualified as a semi-open atoll in the Tuamotu Archipelago context (Andréfouët et al. 2001).

The lagoon presents $~ 1600$ intertidal pinnacles rising from the lagoon floor. Lagoon pinnacles harbour the highest densities of the $P$. margaritifera wild stock, mostly in the 0-20 m depth-range. Pinctada margaritifera is also found naturally on the inner slope of the rim and in the lagoon deep areas, albeit more sparsely.

Pearl oyster farming is an important activity at Raroia with 725 ha of concessions for rearing (i.e., action of growing oysters on artificial supports, before and after grafting) and 733 spat collecting lines authorised by the local authorities in 2016 . The pearl farming activity is spread over the lagoon 
but is more present in the western part of the lagoon. Spat collecting occurs mostly in the southern tier of the lagoon.

\section{Temperature data from in situ sensors}

Lagoon temperature was recorded with high accuracy $\left(+/-0.002{ }^{\circ} \mathrm{C}\right)$ and stability $\left(0.002{ }^{\circ} \mathrm{C} /\right.$ year $)$ using 15 temperature loggers (SBE56, Seabird Scientific ${ }^{\circledR}$ and RBR Duet, RBR $®$ ) deployed over 5 stations (L4, L5, L6, L7, L8, Fig 1B, Table 1). Three of these stations (L4, L5, L6) were located along the slope of lagoon pinnacles. These 3 stations occurred from north to south and are in the central part of the lagoon. Two stations (L7, L8) were set along pinnacles slope but closer to inner slope of the atoll rim, respectively on the West and East side of the lagoon.

Three temperature loggers were deployed at each lagoon stations, along the pinnacles slopes at 2, 8 and 20 meters depth. This array of sensor and sampling strategy allows covering the range of habitats and conditions experienced by oysters. Three temperature loggers were also deployed on the oceanic outer reef slope ( 10 m depth) respectively on the West (station O1), East (O2), and South (O3) sides of Raroia (Fig 1B, Table 1). These sensors were used here for comparing lagoon temperature with ocean temperature.

All temperature loggers were deployed in May 2018 and retrieved in March 2019. Two field trips were necessary to change batteries and retrieve data which induced short (2-4 days) breaks in the time series in August and late November. Depending on loggers, from 293 to 299 days of data provided temperature and therefore could be used for comparison with SST, except for the L6-8 $\mathrm{m}$ logger that stopped prematurely in July 2018 and provided only 273 days for the analysis (Table $1)$.

\section{SST data}

Considering the size of Raroia, a one kilometer resolution was considered to be a minimum for SST data. Lower resolution products $(5 \mathrm{~km}$, or less) would mostly yield mixed pixels covering 
simultaneously part of the lagoon, rim and ocean and therefore not suitable for our objectives. We used two independent global products for satellite-derived-SST data: 1) MUR, which provides daily SST at 0.01 degree (around $1 \mathrm{~km}$ ) resolution (Chin et al., 2017; https://podaacopendap.jpl.nasa.gov/opendap/hyrax/allData/ghrsst/data/GDS2/L4/GLOB/JPL/MUR/v4.1), and 2) Level 4 G1SST, which provides daily SST at $1 \mathrm{~km}$ resolution (Chao et al., 2009; https://podaacopendap.jpl.nasa.gov/opendap/allData/ghrsst/data/L4/GLOB/JPL_OUROCEAN/G1SST/). The spatial resolution of these products provided $\sim 300$ pixels inside Raroia's lagoon.

The SST value provided by these global SST products is an estimate of the so-called 'foundation temperature', or the near-surface temperature below the vertical penetration of diurnal fluctuation due to surface solar heating. In particular, only night time satellite measurements are used by MUR (Chin et al. 2017). Uncertainty on SST (i.e., "analysis error”, provided in degrees), land-mask flags, and time since last $1 \mathrm{~km}$-resolution data, were also extracted and analysed. For each SST value, a confidence interval around the estimate was calculated with SST \pm analysis error.

Data were extracted from May 2018 to March 2019 to match the period of in situ measurements. Pixels on land were discarded from the analysis. Since emerged land of the atoll rim was poorly represented in the MUR and G1SST's land-masks, we used the land feature of the Millennium Coral Reef Mapping Project (Andréfouët et al. 2006) at $30 \mathrm{~m}$ resolution to adequately identify and discard pixels on land. SST time series at each station were computed as the average of SST over the pixels belonging to a $2 \mathrm{~km}$ buffer around the station (Fig. 2). We investigated if matching field data with the corresponding pixel SST value, or with a 2,3 and $5 \mathrm{~km}$ buffer around the field station had any influence on SST values. We found that results were robust and equivalent at all scales (Supplemental file $\mathrm{S} 1$ ) and we kept a $2 \mathrm{~km}$ buffer around stations, as an additional precaution to limit the possible influence of emerging and intertidal patch reefs in low tide conditions. 


\section{Comparison between SST products and in situ temperature}

To compare the daily SST and in situ temperature, we computed the daily-averaged temperature recorded by each logger using two different methods. First, we computed the daily-averaged temperature using both day-time and night-time measurements $\left(T_{24 h}\right)$. Second, we computed the daily-average using only night-time temperature $\left(T_{\text {night }}\right)$, to match the definition of the foundation temperature provided by global SST products (i.e., to prevent sun influence and to better match the hour of satellite data acquisition used by MUR). Night-time recordings were defined as measurements from 00:00 to 04:00 am, local time. This time range is the less affected by solar heating in French Polynesia at any time of year.

To assess and compare the extent by which G1SST and MUR SST are good proxies of lagoon temperature, we first computed the Pearson's correlation coefficient (r) between SST and $T_{24 h}$ and between SST and $T_{\text {night }}$ over the 10-month period covered by this study, using the cor function in stats package in R.3.1.0.

Then, for each temperature time-series recorded by each logger, the agreement between in situ temperature and SST was evaluated by computing the difference $(\Delta T)$ between the two series following equation 1 :

$$
\Delta T_{s, p}=T_{s}-S S T_{p} \quad(\text { eq. } 1)
$$

where $s$ refers to the in situ data used (either "24h" or "night"), and $p$ refers to the global SST product used (either "MUR" or "G1SST"). Since daily temperature data may not be necessarily relevant for physiological processes occurring at longer time-scale (Sangare, 2020), we also calculated $\Delta T$ considering $T_{24 h}$ and SST data averaged over 2, 3, 5, 7 and 15 days respectively, instead of using daily data. 
The difference between $\Delta T$ and 0 was tested using a two-sided student t-test. Normality of residuals were checked with Chapiro-tests. Differences in $\Delta T$ between stations were also tested, using twosided pairwise student t-tests. These statistical analyses were performed using the t.test and chapiro.test functions in stats package in R.3.1.0.

Significance of differences between SST and in situ temperature when modelling P. margaritifera's life traits

Although this paper focuses first on comparison of SST and observations and its variations across Raroia lagoon for different SST products, the ultimate question that motivated this research is whether using SST or in situ temperature, for a variety of pearl farming lagoons, have a significant influence for pearl farming research and monitoring programs and which one are to be recommended. To initiate here this reflexion, we used biases $(\Delta T)$ observed in Raroia to discuss the variability of $P$. margaritifera physiological responses if the species was exposed to this range of temperature variation.

To assess the significance of Raroia' $\Delta T$ values when modelling $P$. margaritifera's physiology and life traits, we used a P. margaritifera bioenergetic Dynamic Energy Budget (DEB, Kooijman, 2010) model which was validated for oysters from Tuamotu atoll lagoons (Sangare et al. 2020). The model described by Sangare et al. (2020) is able to represent the full life cycle of $P$. margaritifera, and is based on Thomas et al. (2011) for larvae and Fournier (2011) for adults. It can predict different $P$. margaritifera life history traits from known food concentration and temperature conditions, the latter is of interest here. These history traits are relevant to spat collection and pearl production, and include the reproductive effort (i.e., number of spawns), the pelagic larval duration (PLD), and growth rates (for larvae, juveniles and adults). A detailed 
description of the model formulation, parameterization and validation is available in Sangare et al. (2020), and

https://www.bio.vu.nl/thb/deb/deblab/add_my_pet/entries_web/Pinctada_margaritifera/Pinctada_ margaritifera_res.html).

Here, we performed a 10-month long simulation corresponding to the Raroia in situ temperature measurement period. We simulated: 1) the reproductive effort (i.e., number of spawns) for a population of fully mature adults with both male and female individuals (start shell length fixed at $13 \mathrm{~cm}$, on the basis of Pouvreau et al. 2000 and Chavez-Villalba et al. 2011) assuming empty gonad at the beginning of the simulation; 2) the pelagic larval duration (PLD, days); and 3) growth rate of juveniles (increment of shell length, $\mu \mathrm{m} /$ day). Due to the low seasonal trend in temperature in the Tuamotu Archipelago, spawning was triggered according to an opportunistic strategy in the model (i.e., no temperature threshold were required for spawning). Since we were interested in temperature effects, during all simulations, food concentration was assumed constant and equal to $0.5 \mu \mathrm{g}$-chla. $\mathrm{L}^{-1}$. This value is the average chl-a measurement recorded in Raroia lagoon on 8 stations during one week (07/12/2019 -15/12/2019, Rodier, unpublished data). This level of food concentration also falls within the range of values that have been reported in atoll lagoons of Tuamotu Archipelago (from $0.1 \mu \mathrm{g}$-chla.L $\mathrm{L}^{-1}$ to $1.2 \mu \mathrm{g}$-chla. $\mathrm{L}^{-1}$, Andréfouët et al. 2001; Thomas et al. 2016). It was also used in Sangare et al. (2020) sensitivity analysis of life traits to food and temperature conditions. Assuming a constant food concentration was not realistic as variations are expected in a 10-month period (see Thomas et al. 2016 for Ahe lagoon for instance), but we were interested by the sensitivity of life traits to temperature variations within a level of uncertainty, and not by accurately simulating life traits across long periods.

Daily data of lagoon temperature during our 10-month study period, extracted from global SST products (i.e., MUR and G1SST) on the first hand, and from in situ temperature series on the other hand, were used as input of the DEB simulations. For growth rate and reproductive effort, nine 
simulations were performed for each lagoon stations (i.e., stations L4, L5, L6, L7, L8). Three of these simulations used daily temperature data from in situ sensors at $\sim 2 \mathrm{~m}, \sim 8 \mathrm{~m}$, and $\sim 20 \mathrm{~m}$ depth, while the six others used the daily SST provided by each SST product. Three simulations were performed for each SST product, using respectively: i) the SST estimates; ii) the lower bound of confidence interval around SST estimates; and iii) the upper bound. For PLD modelling, the same simulation framework was used but, since larvae drift inside the lagoon through water currents, the temperature was averaged (i.e., mean over the 5 lagoon stations).

\section{Results}

General patterns of lagoon and ocean temperature from in situ sensors

Except for L8, in situ temperatures were structured in space with gradually increasing temperatures from the north (station L4) to the south-western (station L7) part of the lagoon (supplemental file S2). However, the spatial differences were small with $97.5 \%$ of $T_{24 h}$ differences between stations below $0.81{ }^{\circ} \mathrm{C}$ at $\sim 2 \mathrm{~m}$ depth, $0.76{ }^{\circ} \mathrm{C}$ at $\sim 8 \mathrm{~m}$ depth, and $0.71{ }^{\circ} \mathrm{C}$ at $\sim 20 \mathrm{~m}$ depth. This horizontal gradient was predominant from October to February and observed more episodically from March to September. Station L8, located in the eastern part of the lagoon, did not follow this horizontal trend and frequently displayed the lowest temperature. These patterns in temperature across the lagoon were observed at all depths (i.e., $\sim 2 \mathrm{~m} ; \sim 8 \mathrm{~m} ; \sim 20 \mathrm{~m}$ ), but it was most pronounced at $\sim 2 \mathrm{~m}$ depth.

Enhanced vertical stratification of temperature due to solar radiation was observed at mid-day all year round at all lagoon stations, with higher daily ranges of temperature at $\sim 2 \mathrm{~m}$ depth (median: $0.48{ }^{\circ} \mathrm{C}$; Q97.5 \%: $1.17{ }^{\circ} \mathrm{C}$ ), than at $\sim 8 \mathrm{~m}$ depth (median: $0.30{ }^{\circ} \mathrm{C}$; Q97.5\%: $0.57{ }^{\circ} \mathrm{C}$ ) and $\sim 20 \mathrm{~m}$ depth (median: $0.17{ }^{\circ} \mathrm{C}$; Q97.5 \%: $0.39{ }^{\circ} \mathrm{C}$ ). During austral summer, from October to March, vertical stratification of temperature was stronger and extended into night-time during several days 
(up to two weeks at L7 and L8 stations, supplemental file S2). During these periods of vertical stratification, differences between $T_{24 h}$ at $\sim 2 \mathrm{~m}$ depth and $T_{24 h}$ at $\sim 20 \mathrm{~m}$ depth reached $0.65{ }^{\circ} \mathrm{C}, 0.68$ ${ }^{\circ} \mathrm{C}, 0.77{ }^{\circ} \mathrm{C}, 1.36{ }^{\circ} \mathrm{C}$, and $0.71{ }^{\circ} \mathrm{C}$ at stations $\mathrm{L} 4, \mathrm{~L} 5, \mathrm{~L} 6, \mathrm{~L} 7$, and $\mathrm{L} 8$ respectively.

During the cool season (i.e., austral winter from June to September), sensors located on forereef oceanic stations (O1-O3) recorded higher temperature than sensors located inside the lagoon, with up to $0.37^{\circ} \mathrm{C}$ differences between reefslope $T_{24 h}$ and lagoon $T_{24 h}$ in late July (mean over all sensors, Fig. 3). By contrast, forereef oceanic temperature was lower than lagoon temperature during the warm season, with up to $0.72{ }^{\circ} \mathrm{C}$ differences between lagoon $T_{24 h}$ and reefslope $T_{24 h}$ in March (Fig. 3). Differences in $T_{24 h}$ between ocean sensors (median: $0.16{ }^{\circ} \mathrm{C}$; Q97.5\%: $0.53{ }^{\circ} \mathrm{C}$; $\max : 0.67{ }^{\circ} \mathrm{C}$ ) were stronger during summer with higher temperature at $\mathrm{O} 1$ (western side of the atoll) compared to $\mathrm{O} 2$ (eastern side), $\mathrm{O} 3$ showing intermediate values. Frequent and short-term drops in temperature with variable magnitudes and frequencies (either 1 or 2 drops per days) affected forereef time series. These drops were never observed on lagoon temperature series, and are most likely generated by open ocean internal waves thus affecting the forereef only. Although they were clearly visible in the high frequency data (supplemental file S2, upper panel) they generated negligible differences in $T_{24 h}$ (supplemental file $\mathrm{S} 2$, lower panel).

\section{Comparison between SST and in situ temperature}

The correlation between SST and in situ temperature was higher for MUR (Pearson's correlation coefficient $r$ from 0.97 to 0.98 depending on sensors/depth) than G1SST (r from 0.92 to 0.94 , table 2). Distributions of $\Delta T_{24 h, G l S S T}$ values were more spread out (ranging from $-1.05{ }^{\circ} \mathrm{C}$ to $+1.93{ }^{\circ} \mathrm{C}$ ) than $\Delta T_{24 h, M U R}$ (from $-0.63{ }^{\circ} \mathrm{C}$ to $1.12{ }^{\circ} \mathrm{C}$; Fig. $4 \mathrm{C}$ ).

The MUR global SST product estimated higher seasonal variability for the lagoon than for the ocean. Indeed, MUR SST was lower inside the lagoon than outside in the cool season, but higher in the warm season (Fig. 2). This seasonal pattern was congruent with in situ temperature, although 
it was slightly underestimated by SST (Fig. 3A). Indeed, significant bias remained with lagoon temperature recorded in situ exceeding the confidence interval of the MUR SST estimates, especially from October to March and in the south-western part of the lagoon (Fig. 3B, station L7). The confidence interval around SST provided by G1SST was wider than MUR's. It usually encompassed both the lagoon and the ocean in situ series (Fig. 3 ; supplemental file S3).

Calculating the daily-mean of temperature recorded by each logger using night-time records only $\left(T_{\text {night }}\right)$ instead of using all records $\left(T_{24 h}\right)$ did not improve the Pearson's correlations with SST (table 2). Values of $\Delta T_{24 h, M U R}$ at $\sim 2 \mathrm{~m}$ depth ranged between $-0.65^{\circ} \mathrm{C}$ and $1.12{ }^{\circ} \mathrm{C}$ with median differences of $0.11^{\circ} \mathrm{C}$. These differences were structured in space, with significantly higher $\Delta T_{24 h, M U R}$ at L7 (up to $1.12{ }^{\circ} \mathrm{C}$ ), than at other stations (paired-t-tests, p <0.001). At L5, L4, L6, and L8 stations, $\triangle T_{24 h, M U R}$ never exceeded $0.81{ }^{\circ} \mathrm{C}, 0.89{ }^{\circ} \mathrm{C}, 0.95{ }^{\circ} \mathrm{C}$ and $0.97{ }^{\circ} \mathrm{C}$, respectively (Fig. 5). For the sensor affected by highest diurnal variability (L7-2 $\mathrm{m}$ ), the distribution of $\Delta T_{n i g h t, M U R}$ values was more centered around 0 than $\Delta T_{24 h, M U R}$ values during the warmest days of the year (Fig. $\left.4 \mathrm{~A}\right)$. At L7-2 m sensor, $\Delta T_{24 h, M U R}$ reached $1.12{ }^{\circ} \mathrm{C}$ whereas $\Delta T_{\text {night,MUR }}$ reached only $0.95{ }^{\circ} \mathrm{C}$. For other sensors, selecting only night-time records in the data induced negligible changes in $\Delta T$ (Fig. 4B).

Values of $\Delta T_{24 h, M U R}$ were also structured in time with $\Delta T_{24 h, M U R}$ significantly higher than zero during the warm season for most sensors in December and January ( $\mathrm{p}<0.001$; Fig. 5). This seasonal trend affected all lagoon sensors and depth but was more pronounced at station L7 at $\sim 2$ $\mathrm{m}$ depth. At this station, $\Delta T_{24 h, M U R}$ was significantly different from zero from October to March ( $\mathrm{p}$ $<0.001$, Fig. 5), with maximal values recorded in October (median: $0.60{ }^{\circ} \mathrm{C}$; min: $0.02{ }^{\circ} \mathrm{C}$; max: $1.12{ }^{\circ} \mathrm{C}$ ). The cool season (May-September) was characterized by lower $\Delta T_{24 h, M U R}$ than other months for all sensors (Fig. 5). In particular, $\Delta T_{24 h, M U R}$ significantly lower than zero were recorded in September for stations L4 and L5, at all depth $(\mathrm{p}<0.05)$. 
Trends in $\Delta T_{24 h, M U R}$ were dependent on sensor depth, with SST estimates more representative of temperature recorded at $20 \mathrm{~m}$ depth than temperature recorded at $2 \mathrm{~m}$ depth (Fig. 3). Indeed, $\Delta T_{24 h, M U R}$ departed from zero with more significance for $2 \mathrm{~m}$-sensors than for $20 \mathrm{~m}$-sensors from October to March, at all stations (Fig. 5). At L7, the maximum values of $\Delta T_{24 h, M U R}$ reached $1.12{ }^{\circ} \mathrm{C}$ for the $2 \mathrm{~m}$-sensor, compared to $0.96{ }^{\circ} \mathrm{C}$ and $0.89{ }^{\circ} \mathrm{C}$ for the $8 \mathrm{~m}$ - and $20 \mathrm{~m}$-sensors. Despite these differences in $\Delta T_{24 h, M U R}$ in relation to depth, similar correlations were found between $T_{24 h}$ and MUR SST at all depths (Table 2).

The MUR SST partially captured the intra-lagoon gradient of temperature, with higher temperature in the south-western part of the lagoon adequately represented for several days during the warm season (Fig 2A). However, the MUR SST usually identified L6 station as the warmest instead of L7 and could not systematically reproduce the spatial horizontal gradient of temperature across the lagoon. For several days, we noted that the true spatial resolution of MUR decreased, masking any temperature difference between Raroia's lagoon and the surrounding ocean (supplemental file S4). The decrease in resolution of MUR during these days induced fast and short (2-4 days) deviation of MUR SST that converged to the temperature recorded on reef slopes (Fig. 3B, supplemental file S2).

Reef slope sensors did not follow the same trend than lagoon sensors regarding their difference with SST. Indeed, the highest values of $\Delta T_{24 h, M U R}$ were found during the cool season (median: 0.14 ${ }^{\circ} \mathrm{C}$ ), and the lowest values of $\Delta T_{24 h, M U R}$ were found in March and November during the warm season (median $\Delta T_{24 h, M U R}:-0.20$ ). Specifically for $\mathrm{O} 1$ and $\mathrm{O} 2, \Delta T_{24 h, M U R}$ was significantly higher than 0 from June to August ( $\mathrm{p}<0.01$ for O1 in June; $\mathrm{p}<0.001$ for O1 in July and August $; \mathrm{p}<0.001$ for $\mathrm{O} 2$ from June to August), and significantly lower than 0 in March $(\mathrm{p}<0.05$ for $\mathrm{O} 1$ and $\mathrm{p}<0.01$ for $\mathrm{O} 2)$. 
As expected, averaging MUR SST and temperature recorded by sensors over several days reduced the range of differences between in situ temperature and MUR SST (Fig. 4E-F). Indeed, the range of $\Delta T_{24 h, M U R}$ was reduced from $1.75^{\circ} \mathrm{C}\left(\Delta T_{24 h, M U R}\right.$ from $-0.63{ }^{\circ} \mathrm{C}$ to $\left.1.12{ }^{\circ} \mathrm{C}\right)$ for daily data, down to $0.67{ }^{\circ} \mathrm{C}\left(\triangle T_{24 h, M U R}\right.$ from $-0.00{ }^{\circ} \mathrm{C}$ to $\left.0.67{ }^{\circ} \mathrm{C}\right)$ for 15 -days-averaged data. However, time averaging did not reduce the median $\Delta T_{24 h, M U R}$ (e.g., $0.29{ }^{\circ} \mathrm{C}$ for daily data compared to $0.32{ }^{\circ} \mathrm{C}$ for 15-days-averaged data) indicating that the filtered signal was equally distributed around the mean.

Significance of differences between SST and in situ temperature when modelling P. margaritifera's life traits

At temperature encountered in Raroia's lagoon and food levels assumed for our simulations, the DEB model predicted a mean PLD of 21 days during the study period. This life trait value was similar when using temperature extracted from global SST products (either MUR or G1SST) and when using in situ temperature data (Table 3). The estimated number of spawning events was also very similar (i.e., 3 spawning events) for all temperature data types used as model input, and for all stations and depths. Using the upper bound of confidence interval around G1SST SST as model input, however, lead to estimate one supplementary spawning events during the study period (Table 3). By contrast, using SST lead to slightly diminish the growth rate of $P$. margaritifera juveniles compared to when using in situ temperature data, except for station L8 at $20 \mathrm{~m}$ depth (Table 3, Fig. 6). Using MUR instead of G1SST provided estimates of growth in slightly better agreement with those estimated from in situ temperature data. In both cases, growth estimated from SST was more representative of growth at $20 \mathrm{~m}$ depth than in shallower habitats. Note that for station L7, using the upper bound of confidence interval around MUR SST instead of using MUR SST itself provided simulations of growth closer to the results based on in situ data, especially for the shallow habitats (Fig. 6). 


\section{Discussion}

Origin of the biases between SST and lagoon temperature at Raroia

In this study, we found a good overall correlation between observations and MUR SST $(0.97<\mathrm{r}<$ 0.98), but significant differences between these two temperature time-series were evidenced, with the highest bias (up to $1.12{ }^{\circ} \mathrm{C}$ ) recorded during the warm season and for the warmest (and shallowest) areas of the lagoon.

The differences between lagoon in situ temperature and SST may result from the combination of several factors. First, the global SST products use complex processing to fill temporal and spatial gaps in SST data induced by cloud cover. Shifting location of original samples and interpolating values between original samples to get SST on a regular grid (i.e., a process called "resampling"), degrades the true resolution of global SST products. Specifically, for MUR, the $1 \mathrm{~km}$ resolution MODIS retrievals used by the analysis are merged with AVHRR (Advanced Very High Resolution Radiometer GAC (9 $\mathrm{km}$ resolution), microwave ( $25 \mathrm{~km}$ resolution) data, and in situ temperature data from oceanic (not atoll lagoon) waters into a Multi-Resolution Variational Analysis (Chin et al. 2017). While this approach performed better than other global SST products in picturing small scale ocean features (Chin et al. 2017), the spatial resolution of MUR is too coarse to depict Raroia's lagoon SST adequately during cloudy periods (supplemental file S4). This is because microwave data at $25 \mathrm{~km}$ resolution predominates in the analysis when higher resolution data of MODIS and AVHRR GAC data are affected by clouds. For Raroia, the reliability of SST varied over time and we notice a significant decrease in accuracy during cloudy days when the time since last $1 \mathrm{~km}$ resolution data exceeded 24h (Fig. 4D). The biases evidenced in this study are therefore most likely explained by these cloudy days when the decreased resolution of global SST product becomes less suitable for atoll lagoons measurements (supplemental file S4). 
Second, lagoon temperatures provided by the global SST products are interpreted and calibrated as open ocean temperature during all steps of the analysis. This includes a data quality screening step that discards outlying SST samples (Chin et al. 2017). However, lagoon temperature is seasonally more variable than ocean temperature because of its lower thermic capacity. Therefore, lagoon pixels could frequently be considered as outliers during the warm season and unfortunately wrongly discarded from the analysis.

Third, land rim of atolls and the small but numerous emerged features in the lagoons (especially at very low tide) are not adequately captured by the land-mask of the global SST product. The extent by which these features affect SST is therefore unknown. Microwave data, in particular, are sensible to land contamination with doubtful estimates within several kilometres of a coast (Chin et al. 2017).

Finally, MUR SST reflects the foundation temperature. The foundation temperature is a concept inherited from open ocean oceanography which is not really relevant for pearl oyster habitats in atoll lagoons. Indeed, the network of temperature loggers deployed at Raroia show that all sensors were affected in some extent by diurnal variability in temperature due to solar heating; even the $\sim 20 \mathrm{~m}$ depth sensors, although in a lower extent than for the $\sim 2 \mathrm{~m}$ depth sensors (supplemental file S2). Using only in situ night records to better match the sampling scheme of global SST products reduced the bias for areas highly affected by solar heating (Fig. 4A). This indicates that lower differences than found in this study between SST and observation can be expected. However, using only night data for the sake of agreement between two sensors would limit the interest of these measurements for pearl farming. All biological species are affected by temperature during day and night. Using only night temperature measurements would be insufficient to properly characterize the environment of these species, including wild and reared pearl oysters. 
Thanks to a wide array of in situ sensors, the heterogeneity of intra-lagoon biases between SST and in situ temperature could be quantified in this study, which has never been done before. Due to the vertical stratification of temperature inside Raroia's lagoon (i.e., lower temperature at $\sim 20 \mathrm{~m}$ depth than at $\sim 8 \mathrm{~m}$ depth and $\sim 2 \mathrm{~m}$ depth), the 'foundation temperature' estimated by global SST products was more representative of temperature recorded at $20 \mathrm{~m}$ depth than temperature recorded at $2 \mathrm{~m}$ depth. Although oysters typically live from the sub-surface down to 10 meters for spat collectors and reared stocks, and from the subsurface down to $\sim 40$ meters for the wild stocks (Zanini and Salvat, 2000; Andréfouët et al. 2016), wild stock is usually in the 0-10 m range in atoll lagoons, therefore where the bias between SST and in situ temperature is the highest.

\section{Comparisons with other atoll lagoons and extrapolation}

To our knowledge, few studies compared in situ lagoon temperature and SST in atoll lagoons. Most coral reef studies that compared SST and temperature recorded by in situ sensors focused on the outer reef slope or very open and exposed lagoons (Sheppard et al. 2009; Castillo and Lima 2010; Claar et al. 2020). While these studies concluded that differences between SST and sensors are mostly due to vertical stratification of water and localized upwelling along the reef slope that generates lower in situ temperature than SST (Sheppard et al. 2009; Claar et al. 2020), processes involved inside closed and semi-closed atoll lagoons remain poorly documented. For these types of lagoons, Van Wynsberge et al. (2017) compared MUR SST from the ocean and MUR SST from the lagoon area with in situ lagoon temperature for three, small, atoll lagoons in French Polynesia and Cook Islands (i.e., Tatakoto 11,5 km², Manihiki $40 \mathrm{~km}^{2}$, and Takaroa $90 \mathrm{~km}^{2}$ ). MUR SST from lagoons did not provide better correlation coefficients with in situ measurements than the oceanic MUR SST, except for the wider lagoon (i.e., Takaroa), for which small improvement in the correlation could be noticed. These results suggested that MUR SST were not suitable for small atoll lagoons, especially for the semi-closed ones (Tatakoto and Takaroa). This motivated Van Wynsberge et al. (2017) to model lagoon temperature from oceanic SST instead of using lagoon 
SST. This exercise, however, cannot be easily done for many atolls, as it required a significant amount of input data for the model (i.e., oceanic SST, wind, tide, wave height, atoll rim geomorphology maps), and still required lagoon in situ temperature data to validate the relationship.

In this study, the extensive sampling of temperature data performed at Raroia allowed us to document processes taking place in a fairly large $\left(359 \mathrm{~km}^{2}\right)$ semi-open atoll. For Raroia's lagoon, we found differences between SST and in situ lagoon temperatures an order of magnitude lower than those documented in Van Wynsberge et al. (2017). The thermal contrast between lagoon and ocean was smaller for the semi-open Raroia compared to semi-closed atolls in Van Wynsberge et al. (2017) ultimately because of the higher rates of exchanges between ocean and lagoon in Raroia (Aucan et al. this issue; Andréfouët et al. 2001). The better agreement between data sets in Raroia suggests that MUR SST inside the lagoon can be a relevant source of temperature data in the case of wide atoll lagoons. This is because the true resolution of SST products were much lower than the lagoon size, except during cloudy days. More pixels mean less likelihood overall of contamination by ocean, land, or clouds, and less likelihood to be considered as outliers when computing the SST product (see previous section).

The 24 pearl farming atoll lagoons in Tuamotu Archipelago are geomorphologically and hydrologically diverse. A number of them are larger than Raroia's lagoon (e.g., $1592 \mathrm{~km}^{2}$ for Rangiroa atoll) and are open to ocean through reef passes and numerous functional hoa. For these relatively wider and more open lagoons compared to Raroia, even lower bias between SST and in situ temperature can be expected. Therefore if one intends to use SST products to characterize atoll lagoons, a case-by-case approach is recommended, taking into account lagoon size and aperture toward ocean. Specifically for the small and/or closed lagoons, atoll-specific, dedicated, studies are required to calibrate the bias between in situ lagoon temperature and SST. 
Consequence for pearl oyster research and management

Modelling thoroughly pearl oyster life traits in a variety of environmental conditions using a DEB model was not the objective of this paper. For this, the reader can refer to Sangare et al. (2020). Instead, here, we used a DEB model only to assess how sensitive the DEB outputs, in term of pearl oyster life traits, are to different temperature data sets.

Despite significant bias evidenced in this study between SST and in situ temperature, $\Delta T$ values documented here remain sufficiently small to have negligible influence on the PLD and the number of spawning events predicted by DEB simulations for Raroia during the 10-month study period. Similarly, the bias in MUR SST result in underestimated juvenile growth (up to $1.9 \mu{\mathrm{m} . d a y^{-1}}^{-1}$ for the warmest area of the lagoon (L7-2 m sensor). For other sensors, the consequences were less than $0.9 \mu \mathrm{m}$. day $^{-1}$ (Table 3 ). Such variations on growth rates may underestimate the time required for oysters to reach grafting size by only a couple of days (Sangare et al. 2020), which is negligible for any farmers, who do not plan their activities and schedules at such level of precision. Thus, global SST products are certainly relevant as input to model pearl oyster physiological processes and population dynamics inside atoll lagoons, like currently done in open marine areas with various sources of temperature data (see Thomas et al. 2011 and Steeves et al. 2018 for examples in temperate coastal areas).

Temperature variations, however, also affect physiological processes of pearl oysters at shorter time scales than tested in this study. Specifically for reproduction, short term variations in temperature ( days) may control spawning, but the ability of global SST products to capture the short term trends in lagoon temperature can be affected by insufficient SST resolution during cloudy days, which could challenge the relevance of using them to predict individual spawning events, or relate observed spawning to environmental conditions. The daily variability of temperature (median found for Raroia at $2 \mathrm{~m}$ depth: $0.48^{\circ} \mathrm{C}$ ) can also affect oyster physiology, but 
is not available from global SST product. More generally, the relevance of using SST for biological applications should be evaluated relative to the time scale of the processes under study.

The present study supports the feasibility of using satellite historical archive to hindcast the temperature regime of some large atolls using satellite products. In fact, beyond the pearl oyster aquaculture atoll case study, the small differences between in situ temperature and SST documented here suggests that temperature conditions can be characterized or revisited, in a cost effective way for many other areas and for many contexts, providing lagoons are wide. This has never been quantified before, making our study an original contribution in the field of coastal oceanography, and for the monitoring of coastal waters found in closed and semi-enclosed settings. On the other hand, this study cannot yet conclude about the feasibility of using satellite data to monitor future temperature conditions. Indeed, the observed range at Raroia during the study period was from $26^{\circ} \mathrm{C}$ to $31{ }^{\circ} \mathrm{C}$. For all life traits, degraded physiological performances of oyster were predicted for temperature over $34.5{ }^{\circ} \mathrm{C}$ (Sangare et al. 2020). Laboratory experiments also evidenced physiological disorders for elevated temperature (i.e., > $34{ }^{\circ} \mathrm{C}$ ) that may lead to mortalities of P. margaritifera, raising concerns for the pearl oyster industry in Tuamotu atolls at horizon 2100 (Le Moullac et al. 2016). The ability of global SST products to capture events of temperature above the thermal limits of $P$. margaritifera remains untested as lagoon temperature did not exceed $31{ }^{\circ} \mathrm{C}$ at Raroia during our study period. As long as this gap of knowledge has not been filled one should be cautious when interpreting high temperature events in atoll lagoons using SST data without local validation (Andréfouët et al. 2018). It is therefore suggested to continue monitoring atolls with in situ sensors and continue the evaluation of SST product in the future while we are heading to a warmer climate. 


\section{Acknowledgements}

This study was funded by the ANR-16-CE32-0004 MANA (Management of Atolls) project. MALIS 1 and MALIS 2, two oceanographic campaigns on board $\mathrm{R} / \mathrm{V}$ Alis (https://doi.org/10.17600/18000582), also made this work possible. We are grateful to the R/V Alis crew, as well as to IRD, Ifremer and DRM electronicians and scientific divers: David Varillon, Bertrand Bourgeois, John Butscher, Chloé Germain, Joseph Campanozzi-Tarahu and Fabien Tertre. The study was co-funded by the DRM OTI project, Contrat de Projet France-French Polynesia, Program 123, Action 2, 2015-2020. Facilities at Tahiti were offered by IFREMER/CIP. We are also grateful to Raroia's inhabitants for their help during fieldwork. The authors acknowledge the Pôle de Calcul et de Données Marines (PCDM) for providing DATARMOR storage and computational resources (URL: http://www.ifremer.fr/pcdm). We thanks four anonymous reviewers for their constructive comments that helped improving the paper.

\section{References}

Andréfouët S, Pagès J, Tartinville B (2001) Water renewal time for classification of atoll lagoons in the Tuamotu Archipelago (French Polynesia). Coral Reefs 20, 399-408.

Andréfouët S, Muller-Karger F, Robinson J, Kranenburg C, Torres-Pulliza D, Spraggins S, Murch B. Global assessment of modern coral reef extent and diversity for regional science and management applications: a view from space. In: Suzuki Y, Nakamori T, Hidaka M, Kayanne H, Casareto BE, Nadaoka K, Ya-mano H, Tsuchiya M (Eds.), 10th International Coral Reef Symposium, Okinawa, Japan (2006). Vol 1, pp. 1732-1745.

Andréfouët S, Dutheil C, Menkes CE, Bador M, Lengaigne M (2015) Mass mortality events in atoll lagoons: environmental control and increased future vulnerability. Global Change Biology, 21(1), 195-205. 
Andréfouët S, Thomas Y, Dumas F, Lo C (2016) Revisiting wild stocks of black lip oyster Pinctada margaritifera in the Tuamotu Archipelago: the case of Ahe and Takaroa atolls and implications for the cultured pearl industry. Estuarine, Coastal and Shelf Science, 182, 243-253.

Andréfouët S, Van Wynsberge S, Kabbadj L, Wabnitz CCC, Menkes C, Tamata T, Pahuatini M, Tetairekie I, Teaka I, Ah Scha T, Teaka T, Remoissenet G (2018) Adaptive management for sustainable exploitation of lagoon resources in remote islands: lessons from a massive El Niñoinduced giant clam bleaching event in the Tuamotu atolls (French Polynesia). Environmental Conservation, Special issue, Humans and Island Environments, 45, 30-40.

Andréfouët S, Genthon P, Pelletier B, Le Gendre R, Friot C, Smith R, Liao V (this issue) The lagoon geomorphology of pearl farming atolls in the Central Pacific Ocean revisited using detailed bathymetry data. This issue.

Aucan J, Le Gendre R, Liao V, Andréfouët S (this issue) Wave induced circulation and water level in a semi-enclosed atoll lagoon. Marine Pollution Bulletin, This issue.

Bell JD, Johnson JE and Hobday AJ (eds) (2011) Vulnerability of Tropical Pacific Fisheries and Aquaculture to Climate Change. Secretariat of the Pacific Community, Noumea, New Caledonia.

Bell JD, Ganachaud A, Gehrke PC, Griffiths SP, Hobday AJ, Hoegh-Guldberg O, Johnson JE, Le Borgne R, Lehodey P, Lough JM, Matear RJ, Pickering TD, Pratchett MS, Gupta AS, Senina I, Waycott M (2013) Mixed responses of tropical pacific fisheries and aquaculture to climate change. Nature climate change $3: 591-599$

Castillo KD, Lima FP (2010) Comparison of in situ and satellite-derived (MODIS-Aqua/Terra) methods for assessing temperatures on coral reefs. Limnology and Oceanography: Methods 8, 107117. 
Chao Y, Li Z, Farrara JD, Hung P (2009) Blending sea surface temperatures from multiple satellites and in situ observations for coastal oceans. Journal of Atmospheric and oceanic technology 26, $1415-1426$.

Chavez-Villalba J, Soyez C, Huvet A, Gueguen Y, Lo C, Le Moullac G (2011) Determination of gender in the pearl oyster Pinctada margaritifera. Journal of Shellfish Research 30, 231-240.

Chin TM, Vazquez-Cuervo J, Armstrong EM (2017) A multi-scale high-resolution analysis of global sea surface temperature. Remote Sensing of Environment 200, 154-169.

Claar DC, Cobb KM, Baum JK (2020) In situ and remotely sensed temperature comparisons on a Central Pacific atoll. Coral Reefs 38(6), 1343-1349.

Donlon CJ, Martin M, Stark JD, Roberts-Jones J, Fiedler E, Wimmer W (2012) The operational sea surface temperature and sea ice analysis (OSTIA) system. Remote Sensing of Environment 116, $140-158$.

DRM (2020) Bulletin statistique. Synthèse des données de la pêche professionnelle, de l'aquaculture et de la perliculture. Direction des Ressources Marines, Papeete, 64 pp

Dutheil C, Andréfouët S, Jullien S, Le Gendre R, Aucan J, Menkes C (this issue) Characterization of South Central Pacific Ocean wind regimes in present and future climate for pearl farming application. Marine Pollution Bulletin, This issue.

Fournier J (2011) Diet and environmental determinism of reproduction of pearl oysters $P$. margaritifera on Aha atoll lagoon (Tuamotu Archipelago, French Polynesia). PhD thesis, Université de la Polynésie Française.

IEOM (2018) Polynésie française, rapport annuel 2018. Institut d'Emission d'Outre-Mer. Paris, $182 \mathrm{pp}$. 
Kooijman S (2010) Dynamic Energy Budget Theory For Metabolic Organisation. Cambridge University Press.

Latchere O, Mehn V, Gaertner-Mazouni N, Le Moullac G, Fievet J, Belliard C, Cabral P, Saulnier D (2018) Influence of water temperature and food on the last stages of cultured pearl mineralization from the black-lip pearl oyster Pinctada margaritifera. PLoS ONE 13(3): e0193863.

Le Moullac G, Soyez C, Latchere O, Vidal-Dupiol J, Fremery J, Saulnier D, Lo Yat A, Belliard C, Mazouni-Gaertner N, Gueguen Y (2016) Pinctada margaritifera responses to temperature and pH : acclimatation capabilities and physiological limits. Estuarine, Coastal and Shelf Science 182, 261269.

Liao V. et al. Better management of pearl farming atoll using in situ measurements and biophysical models: a manager perspective (this issue) Marine Pollution Bulletin.

Newell ND (1953) Expedition to Raroia, Tuamotus. Part 1. Expedition to Raroia, Tuamotus. Part 2. Physical Characteristics of Raroia. Part 3. General Map of Raroia Atoll. Atoll Research Bulletin 31.

Pouvreau S, Gangnery A, Tiapari J, Lagarde F, Garnier M, Bodoy A (2000) Gametogenic cycle and reproductive effort of the tropical blacklip pearl oyster, Pinctada margaritifera (Bivalvia: Pteriidae), cultivated in Takapoto atoll (French Polynesia). Aquatic Living Resources, 13, 37-48.

Reynolds RW and Chelton DB (2010) Comparisons of daily sea surface temperature analyses for 2007-08. Journal of climate, 23(13), 3545-3562.

Reynolds RW, Chelton DB, Roberts-Jones J, Martin MJ, Menemenlis D, Merchant CJ (2013) Objective determination of feature resolution in two sea surface temperature analyses. Journal of climate, 26(8), 2514-2533. 
Rodier, M., Longo, S., Henry, K., Ung, A., Lo-Yat, A., Darius, H., Viallon, J., Beker, B., Delesalle, B., Chinain, M., 2019. Diversity and toxic potential of algal bloom-forming species from Takaroa lagoon (Tuamotu, French Polynesia): a field and mesocosm study. Aquatic Microbial Ecology 83, 15-34. https://doi.org/10.3354/ame01900

Sangare N (2020) Facteurs de variabilité du collectage de naissain de l'huître perlière Pinctada margaritifera dans les lagons des Tuamotu (Polynésie française) et modélisation du collectage. Thèse de doctorat soutenue le 4 Décembre 2019, Université de la Polynésie française, 157 pp.

Sangare N, Lo-Yat A, Le Moullac G, Pecquerie L, Thomas Y, Lefebvre S, Le Gendre R, Beliaeff B, Andréfouët S (2020) Impact of environmental variability on Pinctada margaritifera life-history traits: A full life cycle deb modelling approach. Ecological Modelling 423, 109006.10.1016/j.ecolmodel.2020.109006

Sheppard C (2009) Large temperature plunges recorded by data loggers at different depths on an Indian Ocean atoll: comparison with satellite data and relevance to coral refuges. Coral Reefs 28: 399-403.

Steeves LE, Filgueira R, Guyondet T, Chassé J, Comeau L (2018) Past, Present, and Future: Performance of Two Bivalve Species Under Changing Environmental Conditions. Frontier in Marine Science, 5, 184.

Thomas Y, Mazurié J, Alunno-Bruscia M, Bacher C, Bouget JF, Gohin F, Pouvreau S, Struski C (2011) Modelling spatio-temporal variability of Mytilus edulis (L.) growth by forcing a dynamic energy budget model with satellite-derived environmental data. Journal of Sea Research, 66, 308317.

Thomas Y, Garen P, Pouvreau S (2011) Application of a bioenergetic growth model to larvae of the pearl oyster Pinctada margaritifera L. Journal of Sea Research, 66, 331-339. 
Thomas Y, Dumas F, Andréfouët S (2016) Larval connectivity of pearl oyster through biophysical modelling; evidence of food limitation and broodstock effect. Estuarine, Coastal and Shelf Science $182,283-293$.

Van Wynsberge S, Menkes C, Le Gendre R, Passfield T, Andréfouët S (2017) Are sea surface temperature satellite measurements reliable proxies of lagoon temperature in the south Pacific? Estuarine, Coastal and Shelf Science 199, 117-124.

Zanini JM and Salvat B (2000) Assessment of deep water stocks of pearl oysters at Takapoto atoll (Tuamotu Archipelago, French Polynesia). Coral Reefs 19, 83-87. 


\section{Figure legends}

Figure 1. Study site description. A) Location of Raroia atoll in Tuamotu Archipelago, French Polynesia. B) Geomorphological map of Raroia with location of temperature sensors and pearl farming rearing concessions (source: Direction des Ressources Marines; 2016). Each lagoon station (L4 to L8) was equipped with 3 sensors deployed at $\sim 2,8$ and 20 meters.
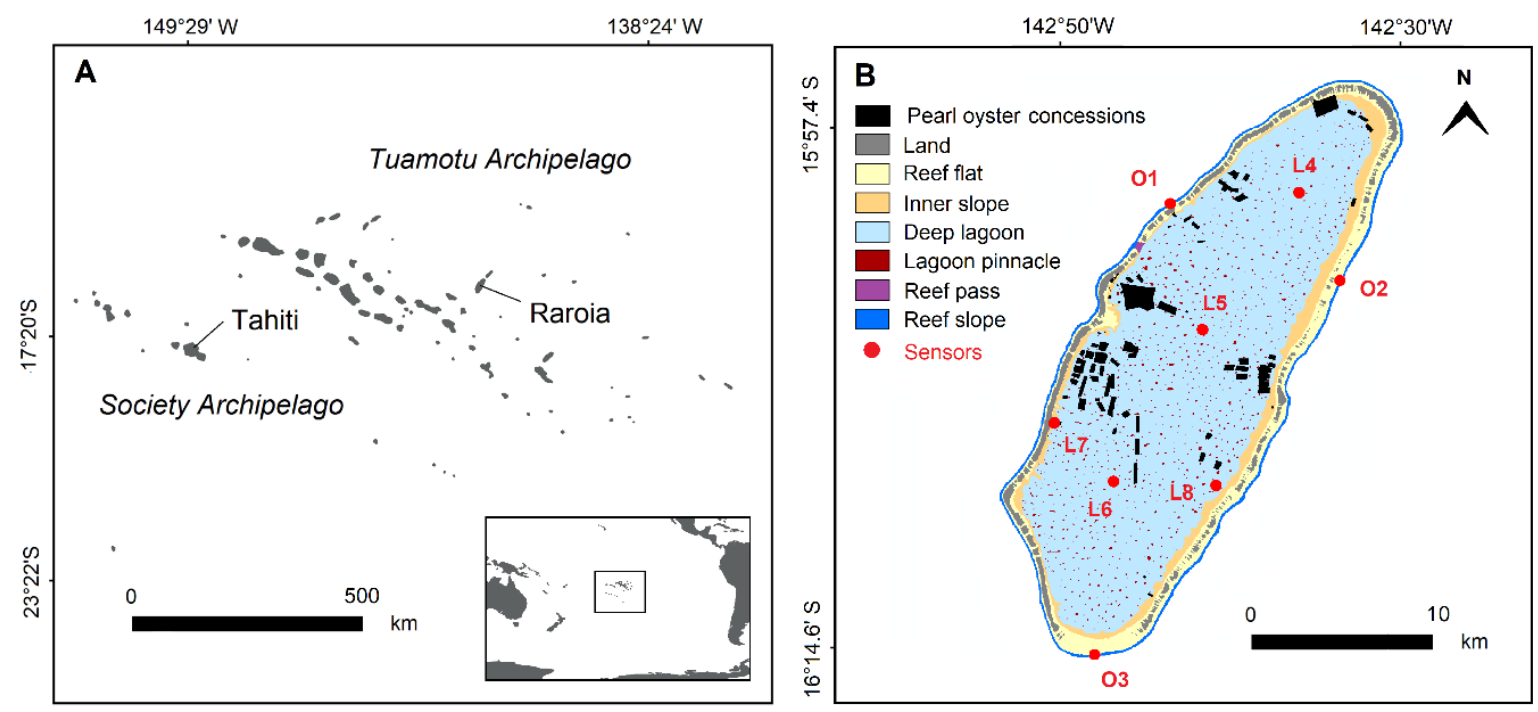
Figure 2. Sea Surface Temperature (SST) around Raroia atoll. A) MUR SST data for 08/02/2019 (warm season). B) MUR SST data for 29/07/2018 (cool season). C-D) same as panels A and B but for G1SST data. Dashed lines delimit the $2 \mathrm{~km}$-buffer area around lagoon loggers, considered in this study for comparison with in situ data.
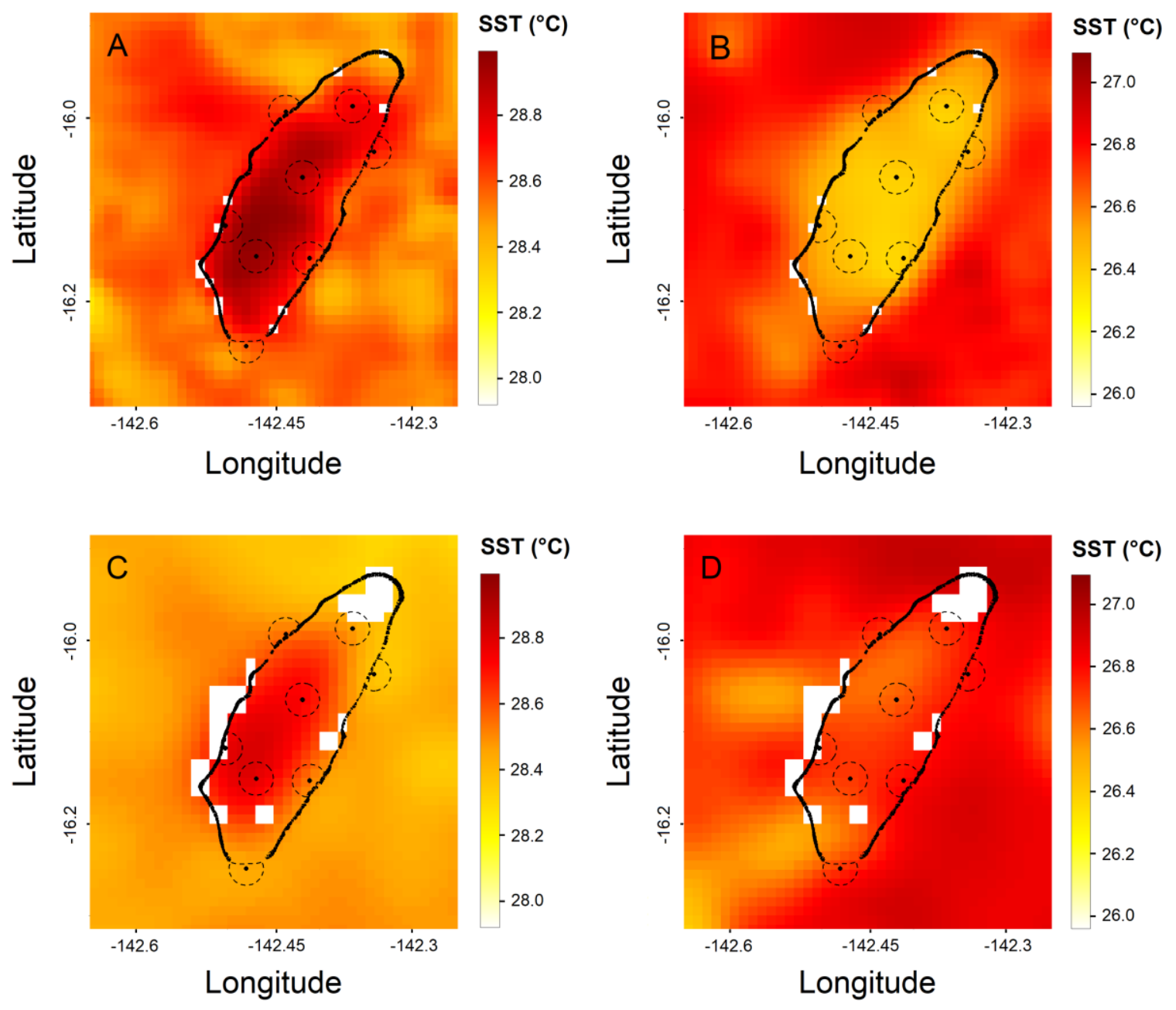
Figure 3. Time series of daily in situ temperatures and MUR SST. A) The green ribbon covers the range of temperature recorded by lagoon sensors (all sensor confounded) and the solid green line is the mean temperature computed from all lagoon sensors. The blue ribbon covers the range of temperature recorded by the three reef slope sensors (all confounded) and the solid blue line is the mean temperature computed from them. The solid red line is the mean of MUR SST over all lagoon stations, and the red ribbon covers the analysis-error associated to MUR SST. B) Similar to panel A) but for L7 station only. In this case solid blue line is the temperature recorded at $\sim 8 \mathrm{~m}$ depth. See supplemental file S3 for similar figures with G1SST instead of MUR, and sensor series based on night-time records only instead of night-time and day-time records.
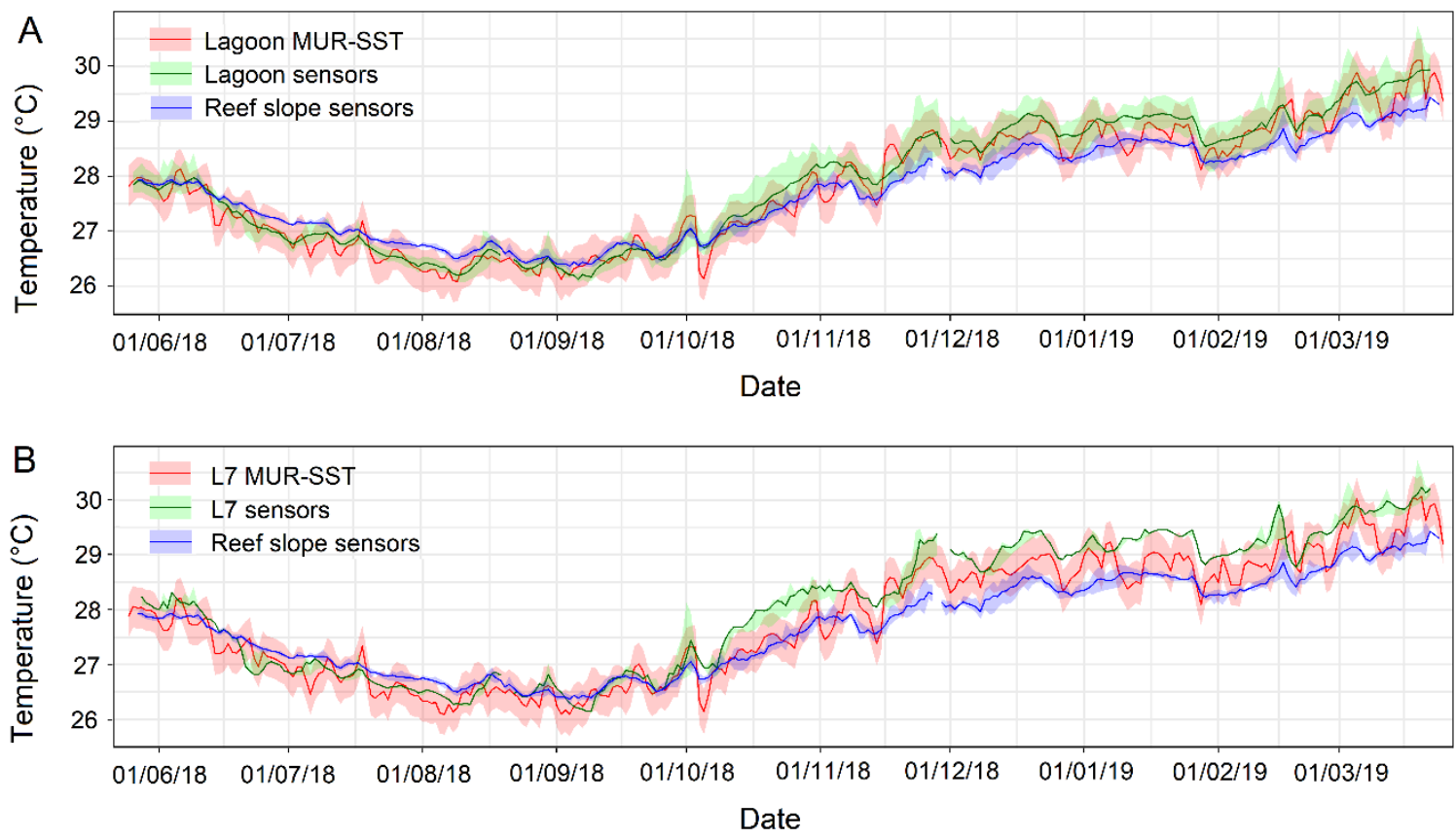
Figure 4. Factors affecting the relationship between temperature recorded by sensors and SST. A-B) Effect of filtering only night records for temperature recorded by sensor versus keeping all (night and days) records on the relationship between MUR SST and in situ temperature $\left(T_{24 h}\right)$, for L7-2 m sensor (A) and L5-8 m sensor (B). C) Effect of considering various global SST products (G1SST versus MUR). D) Effect of time (hours) between the analysis time and the most recent MODIS or VIIRS $1 \mathrm{~km} \mathrm{L2P} \mathrm{datum} \mathrm{on} \mathrm{the} \mathrm{difference} \mathrm{between} \mathrm{in} \mathrm{situ} \mathrm{temperature} \mathrm{and} \mathrm{MUR} \mathrm{SST}$ $\left(\Delta T_{24 h, M U R}\right)$. Missed values were considered as $>48 \mathrm{~h}$ data. E-F) Effect of aggregating sensor and MUR SST data by mean over various time periods for L7-2 $\mathrm{m}$ sensor (E) and L5-8 $\mathrm{m}$ sensor (F) on $\Delta T_{24 h, M U R}$. The wide black dots are medians and black lines links the $25 \%$ and $75 \%$ quantiles. 

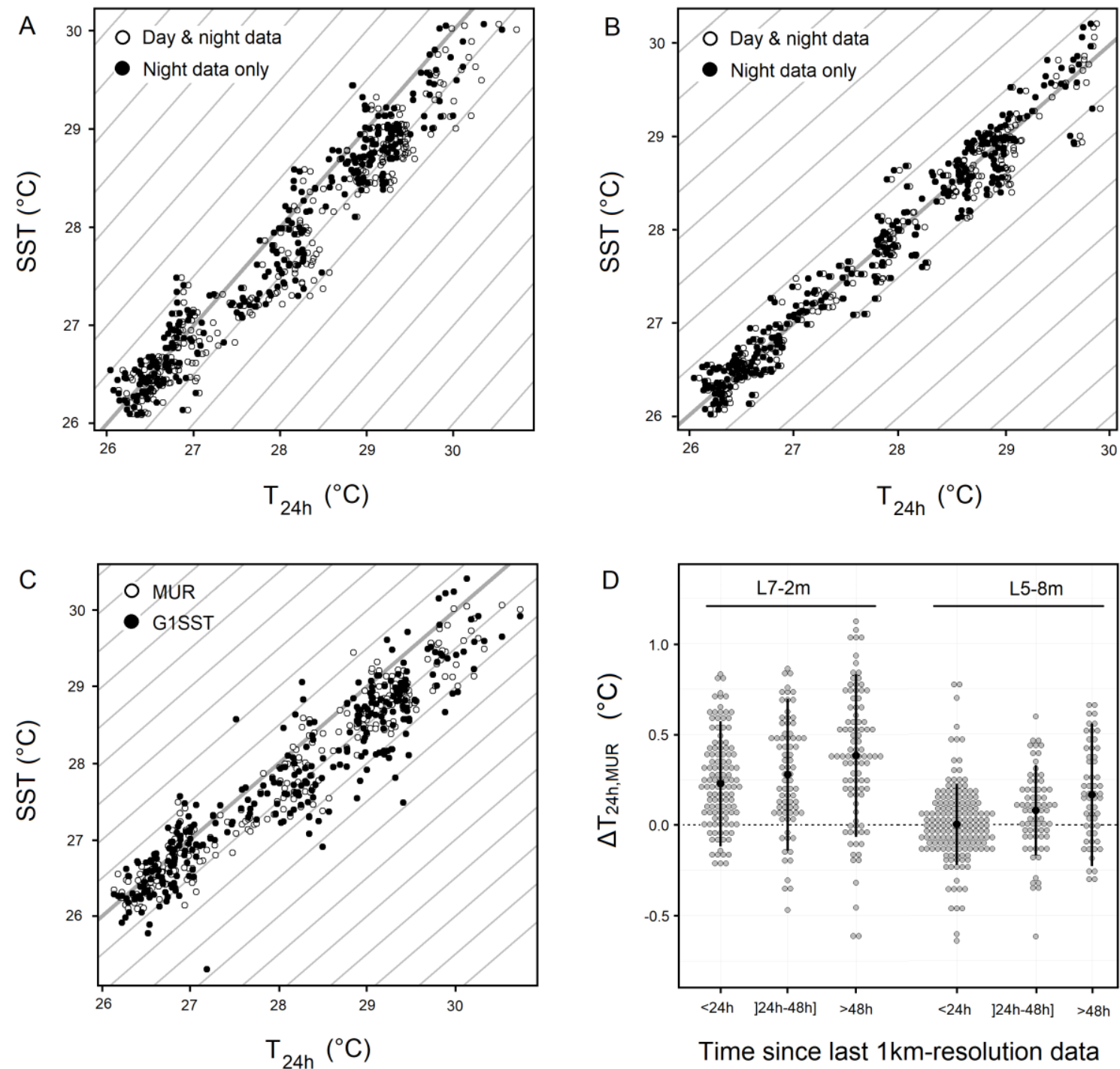

Time since last $1 \mathrm{~km}$-resolution data
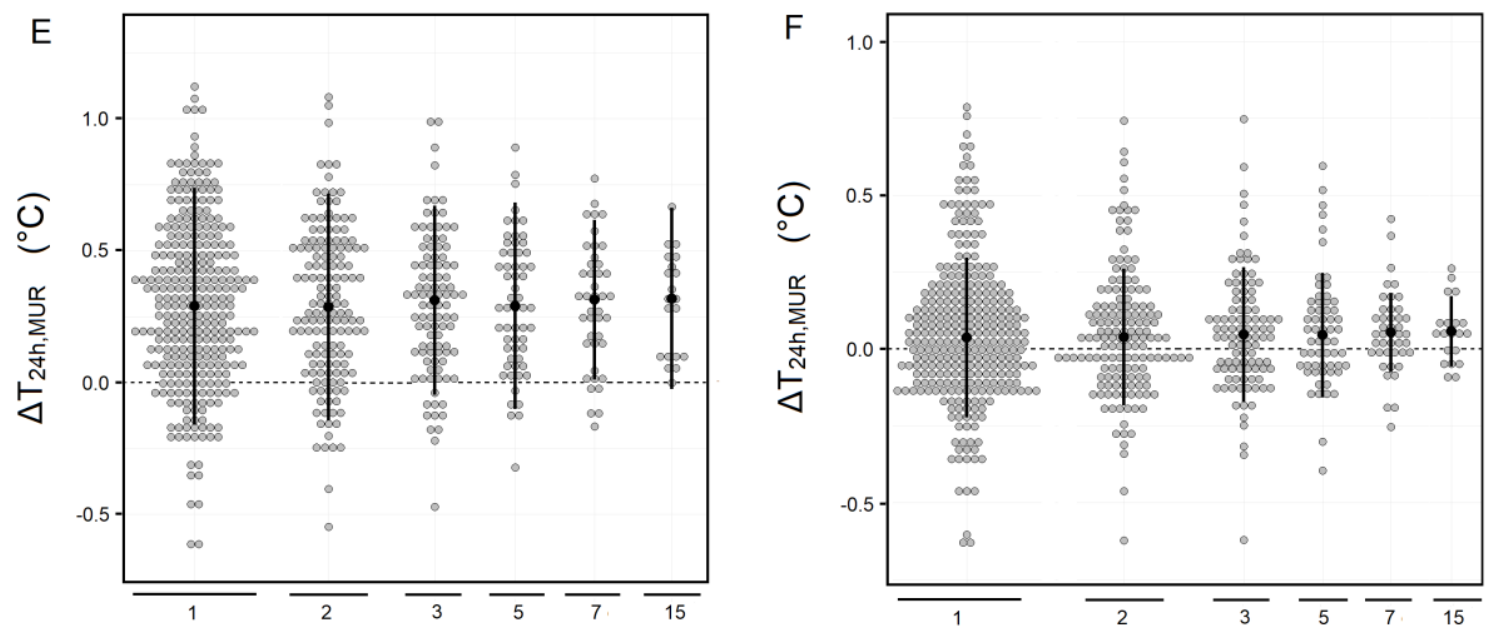

Time period for data aggregation (days)

Time period for data aggregation (days) 
Figure 5. Daily differences between temperature recorded by sensors and MUR SST ( $\left(\boldsymbol{T}_{24 h, M U R}\right)$. A-C) sensors deployed in the lagoon at $\sim 2 \mathrm{~m}$ depth, $\sim 8 \mathrm{~m}$ depth and $\sim 20 \mathrm{~m}$ depth respectively. D) sensors deployed on the reef slope. See Table 1 for sensors specifics and Figure 1 for their locations. Stars highlight significant differences from 0 (student-t-test, $* \mathrm{p}<0.05 ; * * \mathrm{p}<$ $0.01 ; * * * \mathrm{p}<0.001)$ 

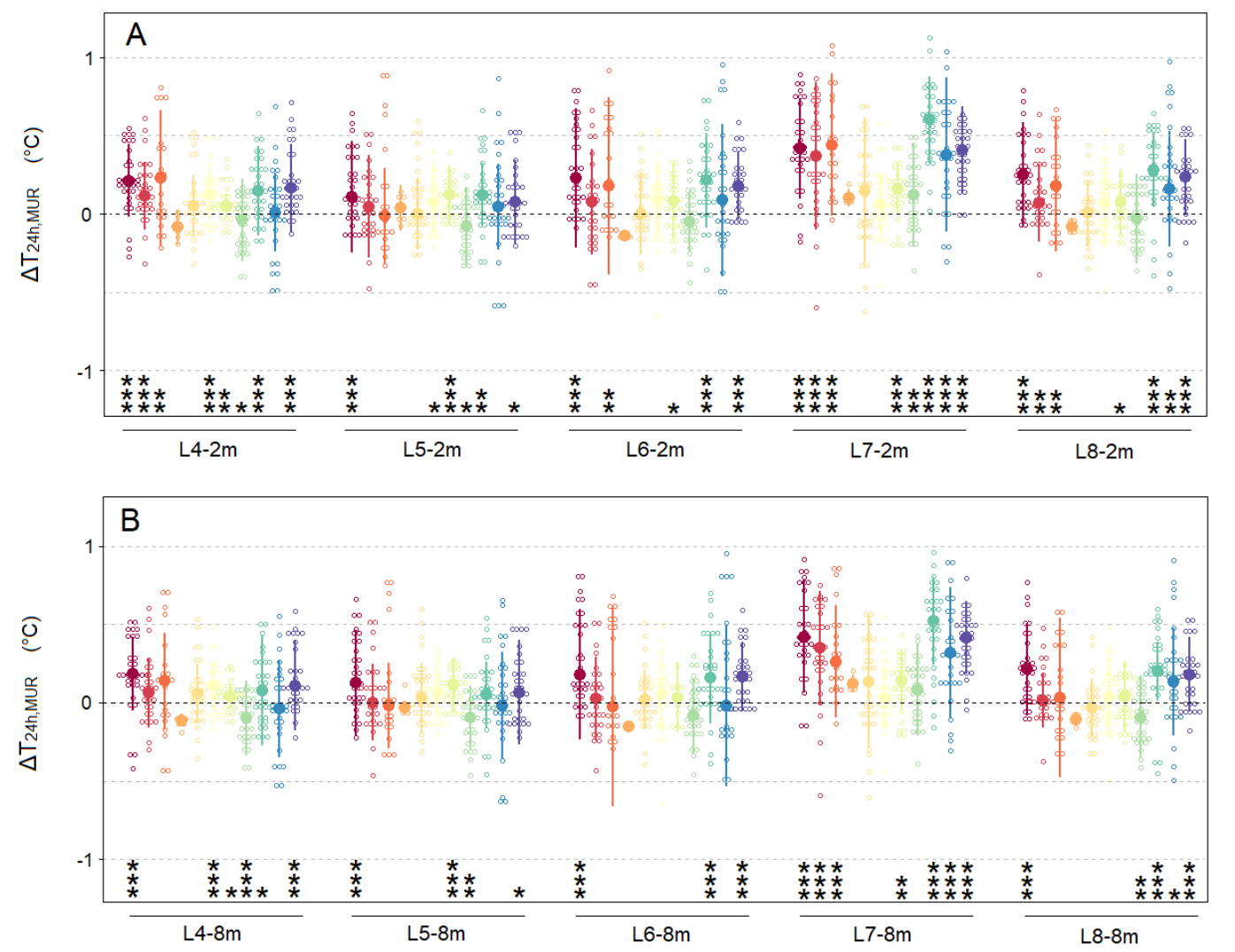

Month

- Jan

- Feb

Mar

May

Jun

Jul

Aug

Sep

Oct

- Nov

- Dec

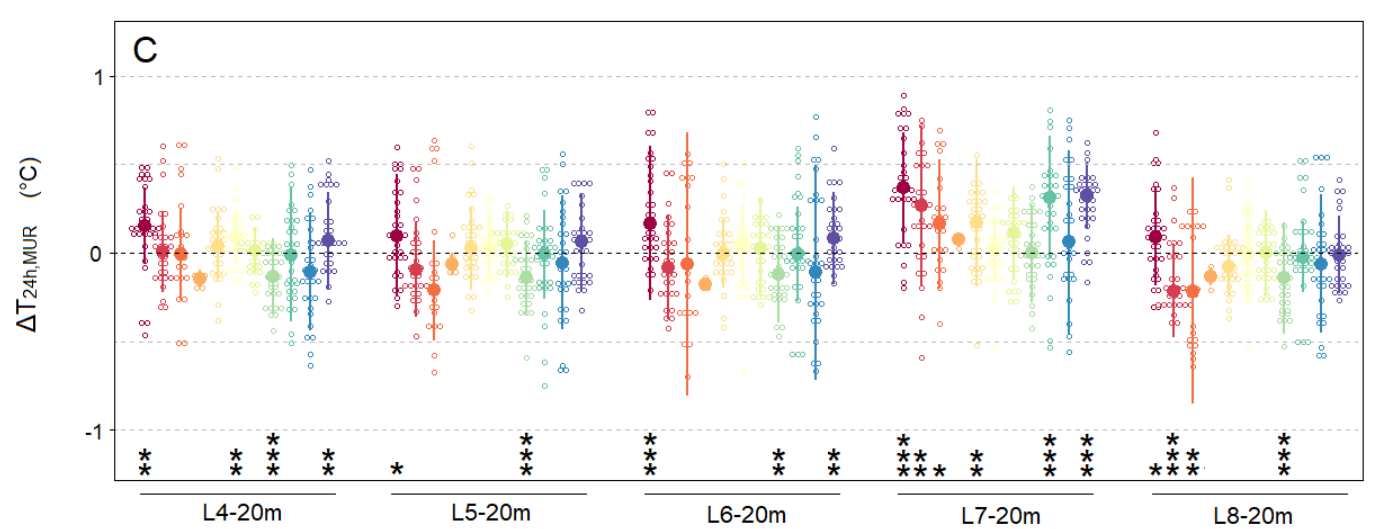

Month

- Jan

- Feb

Mar

May

Jun

Jul

Aug

Sep

Oct

Nov

Dec

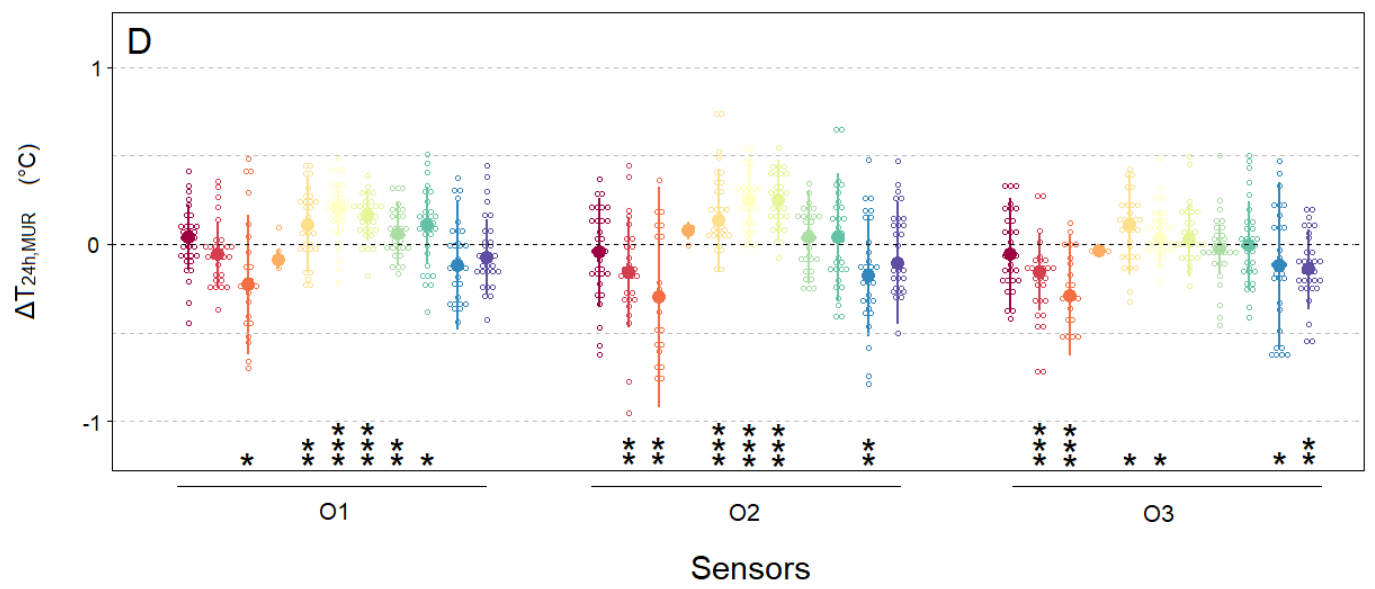

Month

- Jan

- Feb

- Mar

May

Jun

Jul

Aug

Sep

Oct

- Nov

Dec

Sensors 
Figure 6: Estimated growth rate of $P$. margaritifera juveniles from DEB modelling using temperature recorded by sensors (black symbols) or SST (grey symbols) during a 10-months period. Error bars are derived from the error associated to SST.

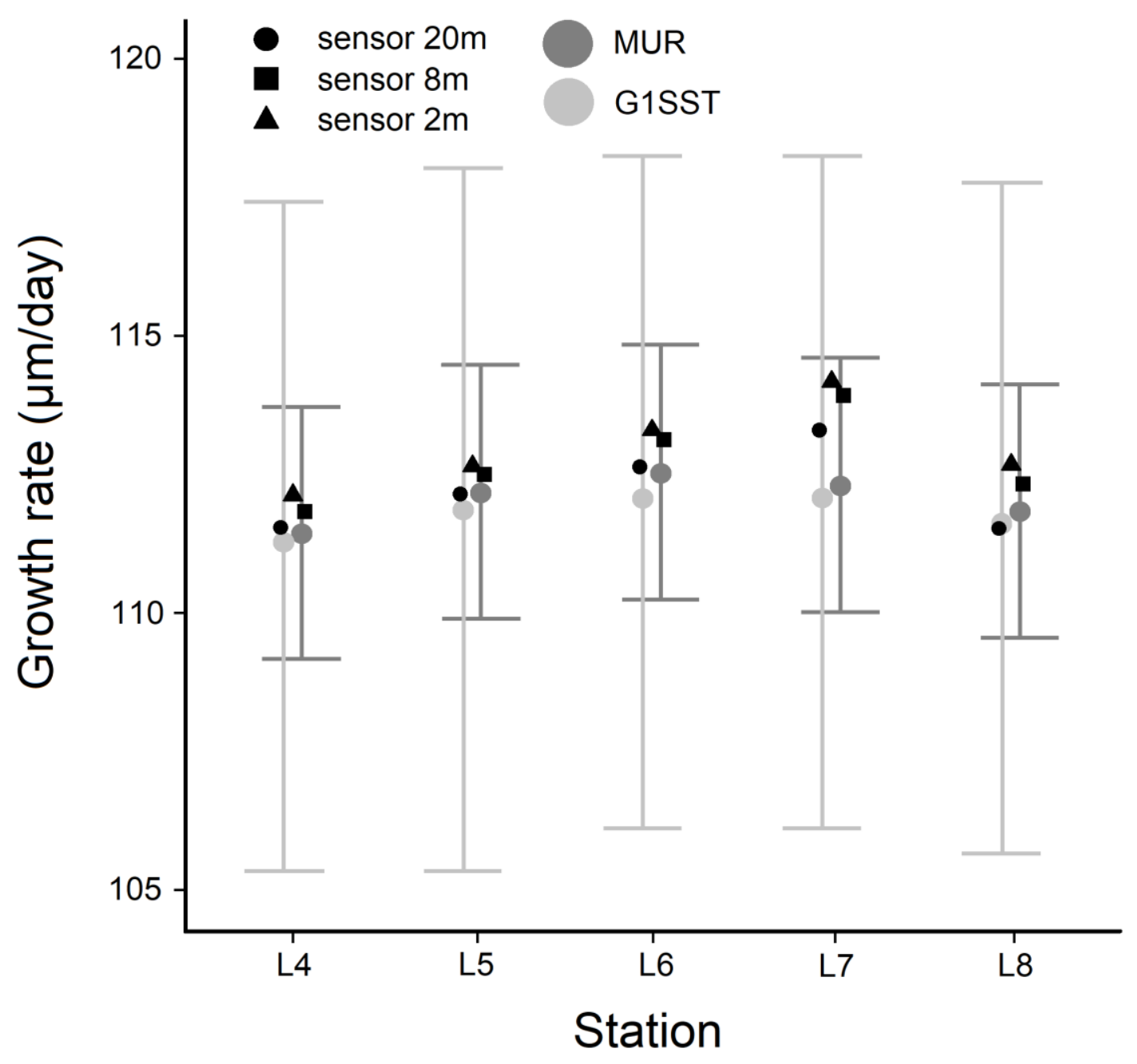


Supplemental file S1: Effect of considering various buffer distances around stations for extracting SST from the MUR global product grids, on differences between in situ temperature and SST $\left(\Delta T_{24 h, M U R}\right)$.

Supplemental file S2: Raw series of temperature recorded by sensors and MUR SST. Upper panel: raw high frequency series. Lower panel : daily mean series $\left(T_{24 h}\right)$ used in this study for comparison with SST. See Table 1 for sensor characteristics and Fig. 1 for exact location of stations.

Supplemental file S3: Time series of daily in situ temperature and G1SST SST. A) The green ribbon covers the range of temperature recorded by lagoon sensors (all sensor confounded) and the solid green line is the mean temperature computed from all lagoon sensors. The blue ribbon covers the range of temperature recorded by the three reef slope sensors (all confounded) and the solid blue line is the mean temperature computed from them. The solid red line is the mean of G1SST series over all lagoon stations, and the red ribbon covers the analysis-error associated to G1SST. B) Similar to panel A) but for L7 station only. In this case solid blue line is the temperature recorded at $\sim 8$ m depth. C) and D): Same as panels A) and B) but using MUR instead of G1SST for SST data, and using only night records for in situ data.

Supplemental file S4: Modis images for a cloudy day and a cloud-free day around Raroia, and resulting spatial resolutions of MUR. A-B) 05/10/18; C-D) 08/02/19. The rim of Raroia atoll is printed in black. Black points refer to the location of sensors and dashed lines to the 2-km buffer around sensors considered in this study. 